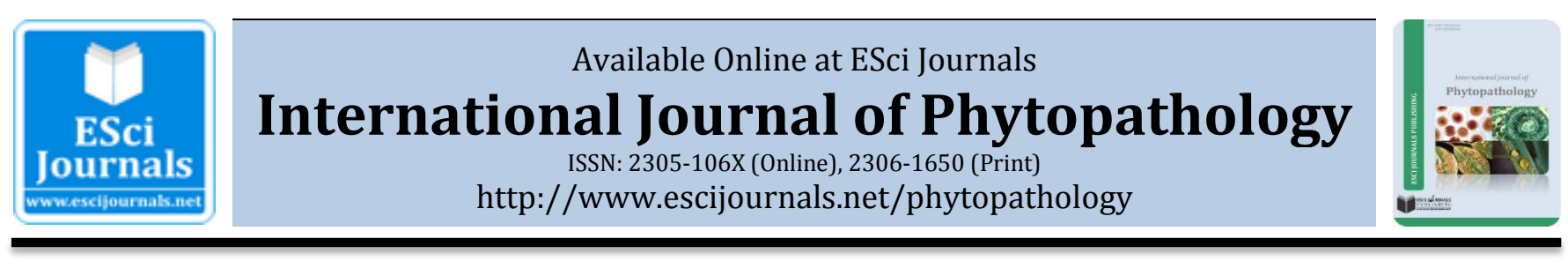

\title{
ROLE OF CERTAIN POTATO TUBERS CONSTITUENTS IN THEIR SUSCEPTIBILITY TO BACTERIAL COMMON SCAB CAUSED BY STREPTOMYCES SCABIES
}

\author{
aKamal A.M. Abo-Elyousr*, bMohamed Hosny, bMahmoud R. Asran, aFarag, A. Saeed \\ a Department of Plant Pathology, Faculty of Agriculture, Assiut University, Assiut, Egypt. \\ ${ }^{\boldsymbol{b}}$ Department of Plant Pathology, Faculty of Agriculture, Sohag University, Sohag, Egypt.
}

\section{A B S T R A C T}

Streptomyces common scab is one of the most bacterial diseases that costs economic loses to potato plants. Streptomyces scabiei (Thaxter 1891) Lambert and Loria (syn. Streptomyces scabies) is the main causal agent of common scab in potato in the field. Eight potato cultivars namely, Diamont, Lady Rossete, Burna, Lady Bellford, Skenta, Flora, Brofent and Everest were tested for their susceptibility to common scab disease under greenhouse conditions. They varied to some extent in the degree of their susceptibility. Lady Rosette appeared to be the highest susceptible one followed by Burna, Everest, and Skenta. Lady Bellford, Diamont respectively, and Brofent showed intermediate disease severity. Flora cultivar exhibited the least degree of scab symptoms. The role of certain potato tubers constituents in the physiology of disease susceptibility was investigated (sugar contents, pectin substances and calcium contents), Lady Bellford cultivar contained the highest concentration of total sugar followed by Flora, Burna, and Everest but Skenta, Lady Rosette respectively and Diamont were approximately had equal in total sugar contents, while, Brofent cultivar contained the lowest content of total sugar. Skenta cultivar contained the highest concentration of pectin substances and calcium contents followed by Flora and Lady Bellford finally Burna cultivars respectively.

Keywords: Potato, Calcium content, common scab, Streptomyces scabies.

\section{INTRODUCTION}

Potato (Solanum tubersum L.) is one of the most important vegetable crops in the world. In Egypt, potato is the $4^{\text {th }}$ most important staple food; the total cultivated area in Egypt was about 318,214 feddans and the total production was about 3.7 million tons according to Food and Agriculture Organization (FAO, 2010), also it is the second most important crop producing energy, in addition to that it is one of the most important export crop in Egypt. Furthermore, potato is a very important source of complex carbohydrates and contains a variety of phytomaterials that have antioxidant activity. It has more protein than corn and nearly double amount of calcium. It also contains iron, potassium, zinc, copper, manganese, vitamin $\mathrm{C}, \mathrm{B}_{6}$ and dietary fibers (Caprara, 2012 and Bastin, 1997).

Common scab disease of potato can cause significant yield and quality losses, and current control methods for

* Corresponding Author:

Email: kaaboelyousr@yahoo.com

(C) 2016 ESci Journals Publishing. All rights reserved. this disease are inadequate (Fyans, et al., 2016 and Hooker, 1981). Methods used to control common scab include chemical treatments of seed potato tubers (Davis, et al., 1976), irrigation (Adams and Lapwood, 1978), changing soil pH (Pavlista, 1992 and Waterer, 2002), rotation strategies ( $\mathrm{Li}$, et al., 1999), use of a tolerant cultivar (Bouchek-Mechiche et al., 2000), and biological control with non-pathogenic streptomycetes (Liu, et al., 1995; Ryan and Kinkel, 1997; Agbessi, et al., 2003 and Arseneault, et al., 2015).

The best management of the disease cannot be achieved without using resistant cultivars, which is easier to apply, cheaper, and acceptable to farmers. (Rich, 1983) mentioned that the most effective method of scab control is to plant resistant cultivars. It has been showed that there is a relationship between levels of some tubers constituents and their susceptibility to common scab disease (Rich, 1983). Many researcher suggested that these constituents such as: calcium, potassium, manganese (Davis et al., 1976) or reducing sugars (Goto, 1981) may play an important role in disease resistance. 
This work is aimed to study the susceptibility of some potato cultivars against common scab, and the role of constituents on their susceptibility to bacterial common scab.

\section{MATERIALS AND METHODS}

Source of Streptomyces scabies the pathogen of common scab disease: Isolate of Streptomyces scabies stc 11 from a diseased potato in Sohag Governorate, Egypt were used. The pathogenicity of this isolate was previously tested by authors (Hosny, et al., 2014).

Susceptibility of certain potato cultivars to common scab disease: Eight potato cultivars namely, Diamont, Lady Rossete, Burna, Lady Bellford, Skenta, Flora, Brofent and Everest were tested for their susceptibility to common scab disease under greenhouse conditions. The cultivation of potato tubers were planted in $20^{\text {th }}$ September 2010.

Healthy potato tubers were planted in $30-\mathrm{cm}$ diameter sterilized pots containing sterile 1:1 soil/sand mixture. Potato tubers were surface disinfected by soaking tubers in $0.5 \%$ sodium hypochlorite for 5 minutes then rinsed twice in sterilized water directly before planting. Fifty $\mathrm{ml}$ of ten days old culture from isolate Stc $11\left(10^{8} \mathrm{CFU} / \mathrm{ml}\right)$ were added to each pot before planting. Five replicate pots for each isolate were used. Pots were arranged in a complete randomized block design with five replicates. Control plants were treated similarly by tap water. The plants were grown in greenhouse under natural temperatures $\left(25 \pm 3^{\circ} \mathrm{C}\right)$. Plants were fertilized every 15 days with urea $46 \%$ (20g/pot) and irrigated with water when necessary. After 90 days from planting tubers of each tested cultivar were harvested and scored for scab severity. Tubers from each replicate were examined for scab symptoms as described before (Hosny, et al., 2014).

Role of certain potato tuber constituents in their susceptibility to bacterial common scab

Pectin contents: The anthrone sulphuric acid methods were used in determining the pectin content of potato tubers (Badour, 1959) as follows:

Anthrone sulphuric acid reagent: The reaction mixture consists of $0.2 \mathrm{~g}$ anthrone, $8 \mathrm{ml}$ absolute ethyl alcohol, $30 \mathrm{ml}$ distilled water and $100 \mathrm{ml}$ concentrated $\mathrm{H}_{2} \mathrm{SO}_{4}$. They were successfully mixe in a conical flask under continuous cooling in ice path. This reagent should be always freshly prepared. Half $\mathrm{ml}$ sample +4.5 $\mathrm{ml}$ anthrone reagent were thoroughly mixed and boiled for 7 minutes. After cooling the absorbency against blank was measured photometrically at $620 \mathrm{~nm}$ using spectrophotometer model "Miltonroy Spectronic 601". A standard curve was prepared using pure pectin.

Pectin fractionation: This was conducted essentially according to Galbraith and Shields, (1981) as follows:

Tissues preparations were first extracted twice with $0.5 \%$ ammonium oxalate-oxalic acid at $90^{\circ} \mathrm{C}$ for 24 hours. After each extraction the residue was separated from the supernatant fluid by centrifugation. To each extract, 8 volumes of absolute alcohol were added, slowly with stirring and mixtures were allowed to stand at $-10^{\circ} \mathrm{C}$ overnight. The resulting precipitates were collected by centrifugation, dried in vacuum over anhydrose $\mathrm{CuSO}_{4}$ for 3 hours, Stored over $\mathrm{P}_{2} \mathrm{O}_{2}$ and designated as pectin fraction 1 and 2, respectively.

\section{Sugar contents}

Extraction and Determination of total sugars: One gram from healthy potato tubers samples was cut into pieces then put in test tube, and $5 \mathrm{ml}$ of $70 \%$ ethanol were added, then tubes were subsequently in water bath at $70^{\circ} \mathrm{C}$ for $72 \mathrm{hrs}$ and left to dry. The residue was dissolved in $5 \mathrm{ml} 50 \%$ iso-propyl-alcohol. All samples were stored at $4^{\circ} \mathrm{C}$ until analyzed.

Eight ten ${ }^{\text {th }} \mathrm{ml}$ of extracted sample was mixed with $5 \mathrm{ml}$ distilled water and $4 \mathrm{ml}$ picric acid reagent in a sterilized test tube. The mixture was boiled on a water bath for 10 minutes then left to cool. One $\mathrm{ml} \mathrm{Na}_{2} \mathrm{CO}_{3}$ $20 \%(\mathrm{w} / \mathrm{v})$ was added to the mixture and boiled for another time on a water bath for 10 minutes then left to cool. The mixture was completed to final volume (50 $\mathrm{ml}$ ) using distilled water. Color optical density of the reacted mixture was measured on absorbance spectrophotometer "Miltonroy Spectronic 601" at 540 nm (Thomas and Dutcher, 1924).

Standard curve of sugar values: One gram of glucose was dissolved in a volume of distilled water and the total volume was made up to one liter. Different concentrations of glucose solutions were prepared in $100 \mathrm{ml}$ of distilled water in volumetric flasks. Eight ten $^{\text {th }} \mathrm{ml}$ of different glucose concentrations was taken separately and mixed with $5 \mathrm{ml}$ distilled water and 4 $\mathrm{ml}$ picric acid reagent in sterilized test tube. The mixture was boiled on a water bath for 10 minutes then left to cool. One $\mathrm{ml} \mathrm{Na}_{2} \mathrm{CO}_{3} 20 \%$ (w/v) was added to the mixture and boiled for another time on a water bath for 10 minutes then left to cool. The mixture was completed to a final volume $(50 \mathrm{ml})$ with distilled 
water. Color optical density of the reacted mixture was measured on absorbance spectrophotometer "Miltonroy spectronic 601 " at $540 \mathrm{~nm}$ and the known concentrations of glucose were plotted for comparison.

Calcium, sodium and potassium contents: Tubers samples were digested using the wet ash with nitric acid $\left(\mathrm{HNO}_{3}\right)$ and Bircholoric acid $\left(\mathrm{HCIO}_{4}\right)$ method following the next steps:

a. Sample of 0.21 gram of oven dry finally ground plant was transferred to tall beaker and $20 \mathrm{ml}$ of concentrated $\mathrm{HNO}_{3}$ witting the entire sample. The beaker was covered with a watch glass and was allowed to stand overnight.

b. Beaker was placed on a hot plate kept inside a fume chamber. Continue heating gently until solid particles nearly disappeared.

c. The beaker was removed from the hot plate and was allowed to cool.

d. Ten $\mathrm{ml}$ of $72 \%$ of $\mathrm{HCIO}_{4}$ was added to the beaker which was placed on a hot plate. Continue heating gently first and the vigorously until dense white fumes formed during heating subsides, and the contents became colorless clear solution.

e. The beaker was cooled, distilled water was added then the contents were stirred with a glass rod and were transferred to $50 \mathrm{ml}$ volumetric flask.

f. Continue transfer of digested residue with portions of distilled water into the same volumetric flask until the entire digest had been quantitatively transferred into the same flask.

g. The volume was made to $50 \mathrm{ml}$ with distilled water and the flask was covered and the contents were mixed by turning the flask upside down 4-5 times and the flask was left to stand overnight.

h. The diluted digest was filtered through a dry Whatman No. 42.

i. The subsequent filtrate was collected and preserved as a sample test solution for the determination.

j. A blank test solution was similarly prepared without plant sample.

Sodium and potassium were measured by flame photometer (CL378- ELICO) while calcium was measured by Atomic Adsorption Spectrophotometer according to (Jackson, 1973).

Statistical analysis: Analysis of variance (ANOVA) was carried out using MSTAT-C program. The Least Significant Difference (LSD) at $\mathrm{P} \leq 0.05$ was applied to detect differences among treatments Gomez and Gomez, (1984).

\section{RESULTS}

\section{Susceptibility of certain potato cultivars to common}

scab disease: The susceptibility of certain potato cultivars to infect with common scab was evaluated. Isolate Stc 11 the highest pathogenic one used in this test. The experiment was conducted in 2010 growing season under greenhouse condition. Data of this experiment presented in figure 1 indicated that the tested potato cultivars susceptible differently for $S$. scabies isolate Stc 11 . They varied to some extent in the degree of their susceptibility. Lady Rosette exhibited the highest susceptibility one followed by Burna, Everest, and Skenta. Lady Bellford, Diamont respectively and Brofent showed intermediate disease severity. Data also indicated that Flora cultivar exhibited the least degree of scab symptoms.

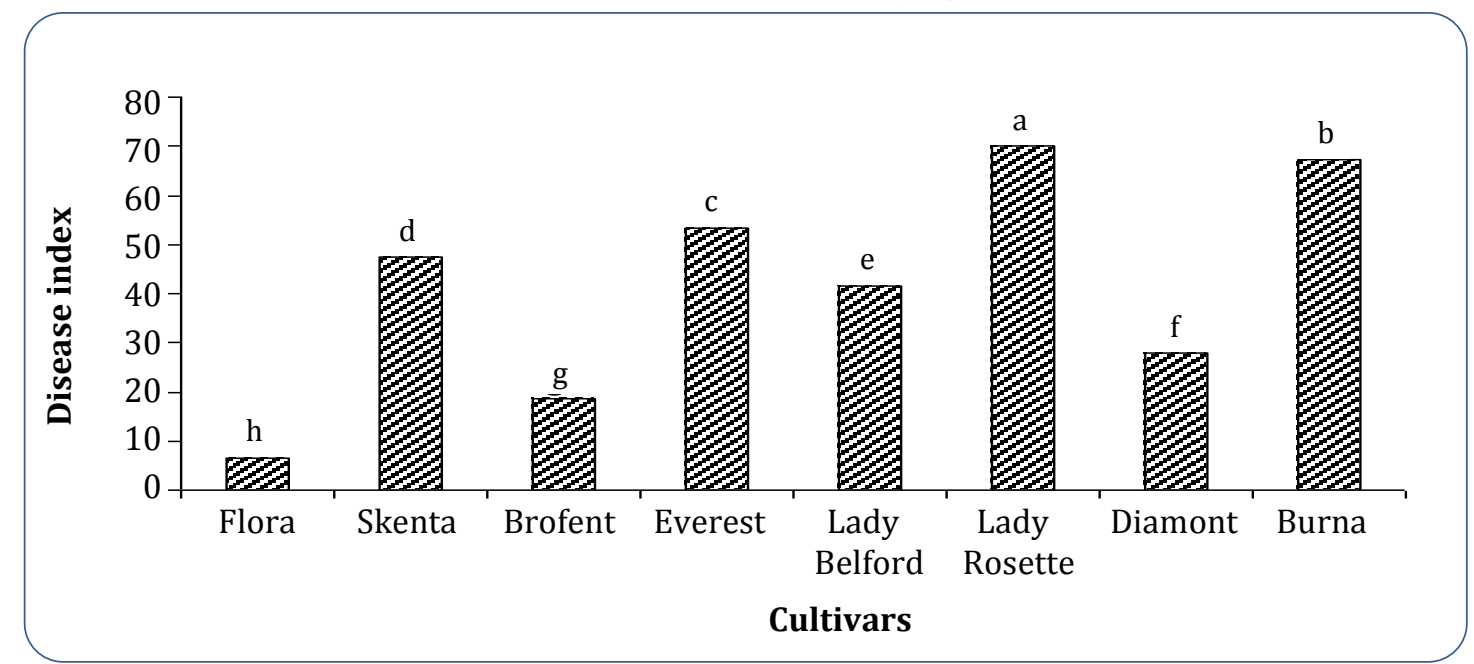

Figure 1. Susceptibility of certain potato cultivars to common scab disease. 
Role of certain potato tuber constituents in their susceptibility to bacterial common scab: The role of total sugar, pectin, calcium, sodium, and potassium contents of potato tubers on their susceptibility to common scab disease was investigated. Healthy potato tubers of eight cultivars were used.

Total sugars: Data in Table. (1) indicated that Lady Bellford cultivar contained the highest concentration of total sugar followed by Flora, Burna, and Everest but Skenta, Lady Rosette respectively and Diamont were approximately equal amount of total sugar contents. Whereas Brofent cultivar contained the lowest content of total sugar.

Pectin contents: Data in Table (1) indicated that the percentages of pectin substances differed by cultivars. Skenta cultivar contained the highest concentration of pectin substances followed by Flora and Lady Rosette, while Burna cultivar contained the lowest concentration of pectin substances.
Table (1). Effects of pectin and sugar potato cultivars contents on susceptibility of bacterial common scab.

\begin{tabular}{lcc}
\hline Potato cultivars & Sugar $(\mathrm{mg} / \mathrm{kg})$ & Pectin $\%$ \\
\hline Flora & $2.38 \mathrm{~b}$ & $0.439 \mathrm{~b}$ \\
Skenta & $1.35 \mathrm{f}$ & $0.528 \mathrm{a}$ \\
Brofent & $0.90 \mathrm{~h}$ & $0.225 \mathrm{e}$ \\
Everest & $1.65 \mathrm{~d}$ & $0.227 \mathrm{e}$ \\
Lady Bellford & $3.53 \mathrm{a}$ & $0.293 \mathrm{~d}$ \\
Lady Rosette & $1.45 \mathrm{e}$ & $0.314 \mathrm{c}$ \\
Diamont & $1.20 \mathrm{~g}$ & $0.210 \mathrm{f}$ \\
Burna & $1.90 \mathrm{c}$ & $0.181 \mathrm{~g}$ \\
\hline LSD & 0.054 & 0.0071
\end{tabular}

Different letters indicate significant differences among treatments within the same column according to L.S.D (Least Significant difference test 5\%).

Calcium, sodium and potassium contents: Data presented in figure 2 indicated that tested cultivars showed different concentrations of calcium, sodium and potassium. Diamont cultivar contained the highest concentration of sodium followed by Burna and Skenta.

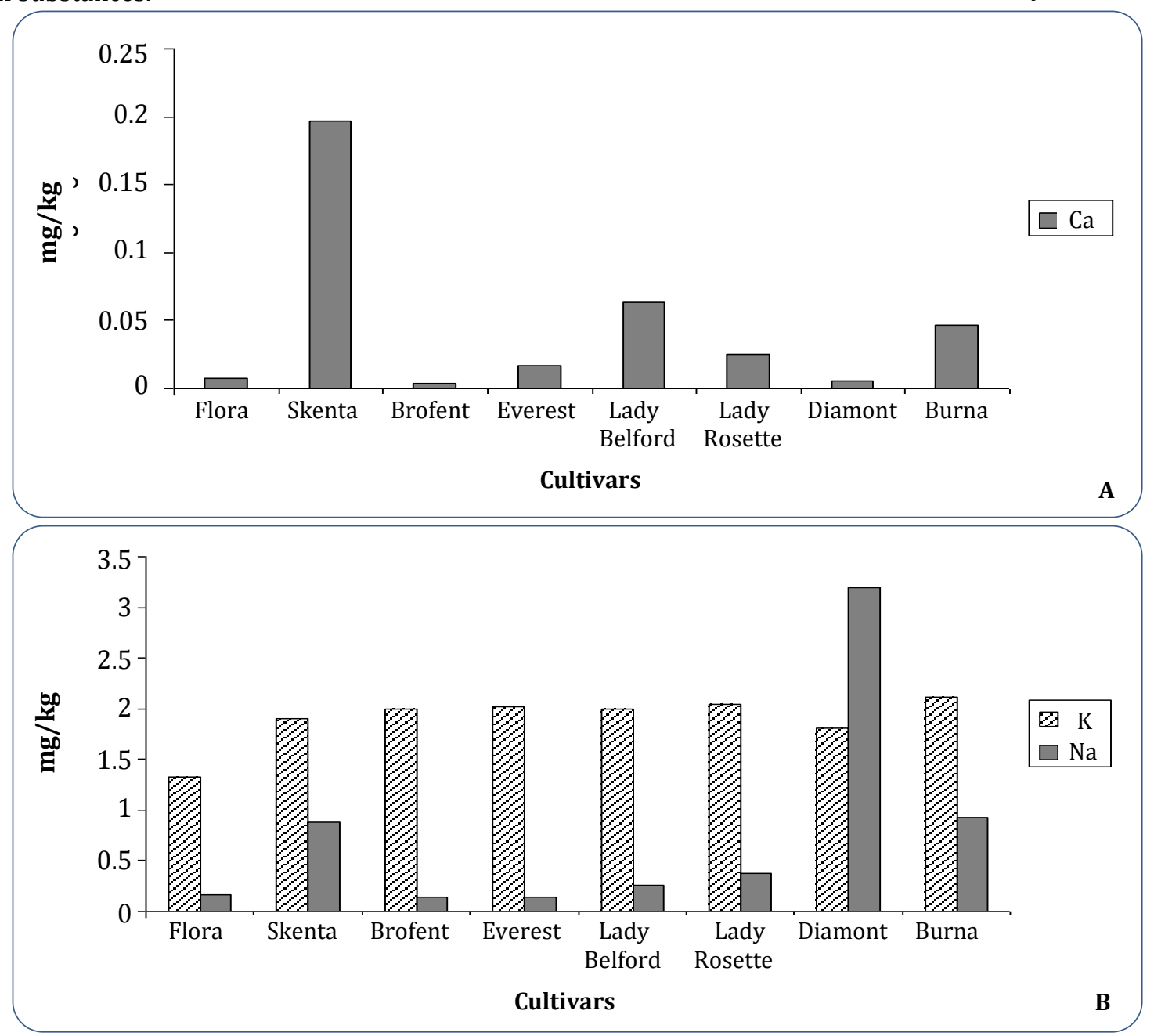

Fig. 2. Potato cultivars contents of sodium and potassium in total tubers (A and B). 
Finally Brofent and Everest contained the lowest concentration of sodium. Also, data indicated that Burna cultivar contained the highest concentration of potassium followed by Lady Rosette, Everest and Lady Bellford. Whereas Flora contained the lowest concentration of potassium. Skenta cultivar contained the highest concentration of calcium followed by Lady Bellford and Burna respectively, whereas Flora, Diamont and Brofent contained the lowest concentration of calcium.

Role of certain potato peel constituents of some potato cultivars on their susceptibility to bacterial common scab: Data in Table (2) indicated that the tested cultivars varied in their peel constituents of calcium, sodium and potassium. Peels of Skenta and Flora cultivars contained the highest concentration of calcium followed by those of Diamont then Lady Bellford and Everest respectively. Whereas peels of Burna, Lady Rosette and Brofent respectively contained the lowest concentration of calcium.

Table (2). Effects of Ca, K and Na potato cultivars peels contents on susceptibility of bacterial common scab (mg/kg).

\begin{tabular}{lccc}
\hline Potato Cultivars & $\mathrm{Ca}$ & $\mathrm{K}$ & $\mathrm{Na}$ \\
\hline Flora & $0.214 \mathrm{a}$ & $2.310 \mathrm{e}$ & $0.857 \mathrm{~d}$ \\
Skenta & $0.214 \mathrm{a}$ & $2.381 \mathrm{~d}$ & $0.881 \mathrm{c}$ \\
Brofent & $0.010 \mathrm{e}$ & $2.548 \mathrm{~b}$ & $0.167 \mathrm{~g}$ \\
Everest & $0.052 \mathrm{c}$ & $2.524 \mathrm{~b}$ & $0.905 \mathrm{~b}$ \\
Lady Bellford & $0.058 \mathrm{c}$ & $2.452 \mathrm{c}$ & $0.143 \mathrm{~h}$ \\
Lady Rosette & $0.017 \mathrm{e}$ & $2.500 \mathrm{~b}$ & $0.524 \mathrm{f}$ \\
Diamont & $0.116 \mathrm{~b}$ & $3.214 \mathrm{a}$ & $1.000 \mathrm{a}$ \\
Burna & $0.034 \mathrm{~d}$ & $2.095 \mathrm{f}$ & $0.667 \mathrm{e}$ \\
\hline LSD & 0.0061 & 0.0269 & 0.0143 \\
\hline
\end{tabular}

Different letters indicate significant differences among treatments within the same column according to L.S.D (Least Significant difference test 5\%).

Peels of Diamont cultivar contained the highest concentration of potassium followed by those of Brofent, Everest, Lady Rosette, and Lady Bellford respectively. Whereas peels of Burna contained the lowest concentration of potassium.

Peels of Diamont cultivar contained the highest concentration of sodium followed by peels of Everest then peels of Skenta and Flora. Finally peels of Brofent and Lady Bellford contained the lowest concentration of sodium.

\section{DISCUSSION}

In the present study the tested potato cultivars were susceptible to common scab disease with some differences in their susceptibility. Tubers of cultivar
Lady Rosette appeared to be the highest susceptible one followed by Burna, Everest, and Skenta. Lady Bellford, Diamont respectively and Brofent showed intermediate disease severity. Data also indicated that Flora cultivar exhibited the least degree of disease severity. Such results are in agreement with those reported by several previous studies (Hiltunen, et al., 2005; Wanner, 2009 and Sedláková, et al., 2013) who reported that potato varieties have a variable response to $S$. scabies presence. However, no variety was symptomatic over all trial.

It should be noted that differences in susceptibility of potato cultivars to common scab disease may be due to certain physiological aspects as well as their constituents of certain antimicrobial contents. To study the role of total sugars, pectin, calcium, sodium, and potassium contents of potato tubers on their susceptibility to common scab disease, healthy potato tubers of eight cultivars were tested. Results indicated that Lady Bellford cultivar contained the highest concentration of total sugar followed by Flora, Burna, and Everest but Skenta, Lady Rosette and Diamont were approximately equal in total sugar contents. Whereas Brofent cultivar contained the lowest content of total sugar.

Data indicated that there is no correlation between tuber contents of total sugars and common scab severity. Also obtained results are disagree with those reported by Goto, (1981) they reported that tubers of scabsusceptible cultivars had more scab and a higher reducing sugar content than those of resistant cultivars. Data indicated that there is a positive correlation between tuber contents of potassium and common scab severity. Burna cultivar contained the highest concentration of potassium followed by Lady Rosette, Everest and Lady Bellford. Whereas there is no correlation between tuber contents of sodium and common scab severity. these results are disagree with those reported by Davis, et al., (1976) who reported that there is a negative correlations between potassium and scab severity and Kristofek, et al., (2000) they reported that significant differences in accumulation of some elements such as $\mathrm{Ca}, \mathrm{P}$ and $\mathrm{K}$ were found between cultivars differing in susceptibility to common scab.

Data indicated that there is a positive correlation between tubers contents of calcium and common scab severity. Skenta cultivar contained the highest concentration of calcium followed by Lady Bellford and Burna, whereas Flora, Diamont, and Brofent contained the lowest concentration of calcium. Such results are in 
agreement with those reported by several workers among them Davis, et al., (1976) who reported that nutrient analysis of petioles collected early in season showed a highly significant positive linear correlation between calcium and scab severity. Also, Horsfall, et al., (1954) and Goto, (1985) mentioned that increased tuber calcium was positively correlated with scab severity.

Data also indicated that there is a negative correlation between peels contents of calcium and common scab severity. Such results are in disagreement with those reported by Kristofek, et al., (2000) and Lambert and Manzer, (1991) they reported that concentrations of mineral elements including calcium in the tuber periderm may not be related to scab incidence or severity.

\section{REFERENCES}

Adams, M. J. and D. H. Lapwood. 1978. Studies on the lenticel development, surface microflora and infections by common scab (Streptomyces scabies) of potato tubers growing in wet and dry soils. Ann. Appl. Biol., 90: 335-343.

Agbessi, S., J. Beause'jour, C. De'ry and C. Beaulieu. 2003. Antagonistic properties of two recombinant strains of Streptomyces melanosporofaciens obtained by intraspecific protoplast fusion. Appl. Microbiol. Biotechnol, 62: 233-238.

Arseneault, T., G. Claudia. 2015. Pseudomonas fluorescens LBUM223 Increases Potato Yield and Reduces Common Scab Symptoms in the Field. Phytopathology,105(10):1311-1317.

Badour, S. S. A. 1959. Amalytisch-Chemische Untersuchung des kalimangels bie Chlorella in Verglgleich mit anderen Mangel Zumstanden Ph. D Dissertation Goettingen.

Bastin, S. 1997. Kentucky Potatoes. Report by the University of Kentucky Cooperative Extension Service, $\mathrm{p}: 1-2$.

Bouchek-Mechiche, K., C. Pasco, D. Andrivonand, B. Jouan. 2000. Differences in host range, pathogenicity to potato cultivars and response to soil temperature among Streptomyces species causing common and netted scab in France. Plant Pathology, 49: 3-10.

Caprara, C. 2012. Potential health promoting properties of potato-derived proteins, peptides and phenolic compounds. In:potatoes production, consumption and health benefits. Nova science Pulishers. Pp173-193.
Davis, J. R., G. M. Mcmaster, R. H. Callihan, F. H. Nissley, and J. J. Pavek. 1976. Influence of soil moisture and fungicide treatments on common scab and mineral content of potatoes. Phytopathology, 66: 228-233.

Food and Agricultural Organization of United Nations, 2010. Agricultural data FAO, 2010. www.fao.org

Fyans, J. K., L. Bown and D. R. Bignell. 2015. Isolation and characterization of plant pathogenic Streptomyces species associated with common scab-infected potato tubers in Newfoundland. Phytopathology, (ja).

Galbraith, D. W. and B. A. Shields. Analysis of the initial stages of plant protoplast development using 33258 Hoechst: reactivation of cell cycle. Physiol. Plant, 51: 380-386.

Gomez, K. A. and A. A. Gomez. 1984. Statistical Procedures for Agricultural Research, $2^{\text {nd }}$ ed. John Willey. New York, 680p.

Goto, K. 1981. The relationship between common scab severity and reducing sugar contents in the peel of potato tubers. Potato Research, 24:171-176.

Goto, K. 1985. Relationships between soil pH, available calcium and prevalence of potato scab. Soil Science and Plant Nutrition 31: 411-418.

Hiltunen, L. H., A. Weckman, A. Ylhäinen, H. Rita, E. Richter and J.P.T. Valkonen. 2005. Responses of potato cultivars to the common scab pathogens, Streptomyces scabies and S. turgidiscabies. Ann. Appl. Biol., 146: 395-403.

Hooker, W. J. 1981. Compendium of potato diseases. American Phytopathological Society. St. Paul. Minnesota, P: 33-35.

Horsfall, J. G., J. P. Hollis and H. G. M. Jacobson. 1954. Calcium and potato scab. Phytopathology, 44: 19-24.

Jackson, M. L. 1973. Soil chemical analysis. Prentic-Hall Inc. U.S.A.

Kristofek, V., J. Divis, I. Dostalkov and J. Kalcik. 2000. Accumulation of mineral elements in tuber periderm of potato cultivars differing in susceptibility to common scab. Potato Research, 43: 107-114.

Lambert, D. H. F. E. and F. E. Manzer. 1991. Relationship of calcium to potato scab. Phytopathology, 81: 632-636.

Li, H. L. E., C. Parent, Tremblay and Karam, A. 1999. Potato response to crop sequence and nitrogen fertilization sod breakup in a Gleyed Humo-Ferric 
Podzol. Canadian Journal of Plant Science, 79: 439-446.

Liu, D., N. A. Anderson and L. L. Kinkel. 1995. Biological control of potato scab in the field with antagonistic Streptomyces scabies. Phytopathology, 85: 827-831.

Pavlista, A. D. 1992. Common scab: control of common scab with sulfur and ammonium sulfate. Spudman 11: 13-15.

Rich, A. E. 1983. Potato diseases. New York: Academic Press.

Ryan, A. D. and L. L. Kinkel. 1997. Inoculum density and population dynamics of suppressive and pathogenic Streptomyces strains and their relationship to bacterial control of potato scab. Biol. Control, 10: 180-186.
Sedláková, V., J. Dejmalová, P. Dolezal, E. Hausvater, P. Sedlák and P. Bastová. 2013. Characterization of forty-four potato varieties for resistance to common scab, black scurf and silver scurf. Crop Protection, 48: 82-87.

Thomas, W. and R. A. Dutcher. 1924. The determination of carbohydrate in plants by picric acid reduction method. The estimation of reducing sugar and sucrose. Journal of American Chemistry Science, 46 (6): 162-166.

Wanner, L. A. 2009. A patchwork of Streptomyces species isolated from potato common scab lesions in North America. American Journal of Potato Research, 86: 247-264.

Waterer, D. 2002. Impact of high soil pH on potato fields and grade losses to common scab. Canadian Journal of Plant Science, 82 (3): 583-586. 